\title{
Sistem Informasi dan Manajemen Pemberkasan Perkara di Kejaksaan Negeri Mempawah
}

\author{
Sandra Aliska ${ }^{\# 1}$, Novi Safriadi ${ }^{\# 2}$, Narti Prihartini ${ }^{\# 3}$ \\ * Program Studi Informatika Fakultas Teknik Universitas Tanjungpura \\ Jl. Prof. Dr. H. Hadari Nawawi, Kota Pontianak, 78115 \\ ${ }^{1}$ aliskasandra@gmail.com \\ ${ }^{2}$ safriadieinformatics. untan.ac.id \\ ${ }^{3}$ narti.prihartini@gmail.com
}

\begin{abstract}
Abstrak - Sebagai salah satu bagian dari lembaga pemerintahan, penggunaan sistem informasi menjadi sangat penting dalam membantu kinerja Kejaksaan Negeri Mempawah guna terselenggaranya pelayanan yang baik dan efektif kepada masyarakat. Adapun tugas utama Kejaksaan Negeri Mempawah tidak terlepas dari aktifitas penanganan berkas perkara. Oleh karena itu tujuan dari penelitian ini adalah menghasilkan suatu sistem informasi yang dapat membuat, mengolah dan mengarsipkan data pemberkasan perkara di Kejaksaan Negeri Mempawah. Alat dalam perancangan sistem ini adalah Data Flow Diagram (DFD), dan pengujian sistem menggunakan metode Blackbox serta User Acceptance Test (UAT) menggunakan kuesioner dengan 10 responden yaitu jaksa sebagai pengguna sistem informasi. Hasil perhitungan kuesioner menggunakan skala likert. Perancangan penelitian ini menghasilkan sistem informasi dan manajemen yang membantu kinerja aparatur Kejaksaan Negeri Mempawah untuk mengelola berkas-berkas perkara di Kejaksaan Negeri Mempawah. Hasil persentase perhitungan kuesioner pada penelitian ini adalah $\mathbf{8 9 , 2 \%}$ yang menunjukan bahwa Sistem Informasi dan Manajemen Pemberkasan Perkara sangat memuaskan dan sesuai dengan harapan dari Kejaksaan Negeri Mempawah.
\end{abstract}

Kata kunci - Kejaksaan Negeri Mempawah, Sistem Informasi, Manajemen, Pemberkasan Perkara.

\section{PENDAhuluan}

Sebagai salah satu bagian dari lembaga pemerintahan, Kejaksaan Negeri tidak terlepas dari penggunaan sistem informasi. Hal ini menjadi sangat penting dalam membantu kinerja Kejaksaan Negeri Republik Indonesia guna terselenggaranya pelayanan yang baik dan efektif kepada masyarakat,

Berdasarkan Undang-Undang Nomor 16 Tahun 2004 bahwa Kejaksaan Republik Indonesia adalah lembaga pemerintahan yang melaksanakan kekuasaan Negara di bidang penuntutan serta kewenangan lain berdasarkan Undang-
Undang. Dalam pelaksanaan kekuasaan Negara khususnya di bidang penegakan hukum diselenggarakan oleh Kejaksaan Agung, Kejaksaan Tinggi dan Kejaksaan Negeri dan masingmasing tingkatan Kejaksaan mempunyai wilayah hukum. Kejaksaan Agung yang berkedudukan di Ibukota Negara Republik Indonesia dan daerah hukumnya meliputi wilayah kekuasaan Negara Republik Indonesia, Kejaksaan Tinggi berkedudukan di ibukota provinsi dan daerah hukumnya meliputi wilayah provinsi dan Kejaksaan Negeri berkedudukan di Ibukota kabupaten/kota yang daerah hukumnya meliputi daerah kabupaten/kota.

Dalam melaksanakan fungsi, tugas, dan wewenangnya, Kejaksaan Republik Indonesia yang melaksanakan kekuasan Negara di bidang penuntutan harus mampu mewujudkan kepastian hukum, ketertiban hukum, keadilan dan kebenaran berdasarkan hukum dan mengindahkan norma-norma keagamaan, kesopanan dan kesusilaan serta wajib menggali nilai-nilai kemanusiaan hukum dan keadilan hidup dalam masyarakat.

Terkait dengan tugas utama Kejaksaan, Kejaksaan Negeri Mempawah tidak terlepas dari aktivitas penanganan berkas perkara untuk segera dilakukan penuntutan, baik perkara Pidana Umum maupun Pidana Khusus. Pada saat ini mekanisme penanganan berkas perkara di Kejaksaan Negeri Mempawah masih dilakukan secara konvensional, dimana berkas perkara diketik dan dengan komputer kemudian dicetak dan diarsipkan pada lemari arsip. Hal ini dapat menyulitkan Kejaksaan Negeri Mempawah dalam mencari berkas-berkas perkara, pembuatan laporan bulanan dan tahunan, overload arsip, dan semua ini menyebabkan waktu pemberkasan perkara menjadi tidak efisien.

Untuk mengatasi permasalah tersebut, dibutuhkan sistem yang dapat mengelola berkas perkara sehingga sebuah perkara yang sedang ditangani oleh Kejaksaan Negeri Mempawah dapat diketahui status perkaranya, misalnya lama perkara, siapa jaksa yang menangani dan status terakhir dari perkara tersebut. Sistem juga diharapkan dapat membuat, 
mengolah dan mengarsipkan berkas-berkas perkara yang ada pada bagian pidana umum dan pidana khusus guna kemudahan pembuatan laporan bulanan dan tahunan sebagai kontrol kepada Kepala Kejaksaan Negeri Mempawah.

Berdasarkan latar belakang yang telah dipaparkan maka penulis akan melakukan analisis, perancangan sebuah Sistem Informasi dan Manajemen Pemberkasan Perkara di Kejaksaan Negeri Mempawah.

\section{URAIAN PENELITIAN}

\section{A. KEJAKSAAN NEGERI MEMPAWAH}

Kejaksaan berdasarkan Undang-Undang Republik Indonesia Nomor 16 Tahun 2004 Tentang Kejaksaan Republik Indonesia Bab 1 Ketentuan Umum Pasal 2 Ayat 1 adalah lembaga pemerintahan yang melaksanakan kekuasaan Negara di bidang penuntutan [1].

Kejaksaan Negeri pada awalnya dibentuk dengan keputusan presiden atas usul Jaksa Agung. Kejaksaan Negeri (Kejari) Mempawah adalah lembaga kejaksaan yang berkedudukan di ibukota kabupaten/kota Mempawah dan daerah hukumnya meliputi wilayah kekuasaan. Kejaksaan Negeri dipimpin oleh Kepala Kejaksaan Negeri (Kajari) yang mengendalikan pelaksanaan tugas dan wewenang kejaksaan di daerah hukumnya (dalam hal ini Mempawah). Kejaksaan Negeri Mempawah merupakan salah satu institusi penegakan hukum yang menyadari sepenuhnya pentingnya pengelolaan yang baik terhadap dokumentasi dan sistem informasi.

\section{B. SISTEM INFORMASI MANAJEMEN}

Sistem Informasi adalah kombinasi dari hardware, software, dan user ysng membentuk sebuah sistem bertugas menerima data lalu mengolah data tersebut menjadi sebuah informasi yang sesuai dengan tujuan tertentu. Manajemen adalah suatu proses unik dan khas yang terdiri dari atas tindakan-tindakan perencanaan, pengorganisasian, serta penggerakan dan pengendalian yang dilakukan guna menentukan arah serta mencapai tujuan yang telah ditentukan sebelumnya melalui sumber daya manusia serta sumber daya lain [2].

Sistem Informasi Manajemen (SIM) merupakan sebuah aplikasi sistem informasi yang digunakan dalam mendukung bentuk bentuk pengelolaan [3].

Jadi sistem informasi manajemen pemberkasan perkara adalah proses yang terjadi adalah semua informasi yang berkenaan dengan perkara (pada kejaksaan negeri mempawah) akan diolah oleh sistem, kemudian semua output yang dihasilkan dari sistem informasi perkara akan dirancang, diorganisir dan diolah guna menghasilkan tujuan yang telah direncanakan sebelumnya

\section{PEMBERKASAN PERKARA}

Berkas perkara adalah kumpulan formulir dan dokumen baik yang dibuat oleh para pihak maupun pengadilan dalam menyelesaikan suatu perkara [4]. Berkas perkara adalah kumpulan dan seluruh kegiatan dan atau keterangan yang berkaitan dengan tindakan penyidikan tindak pidana dalam bentuk produk tertulis yang dilakukan oleh penyidik atau penyidik pembantu.

Dalam penanganannya, beberapa berkas perkara dibuat oleh Kepolisian, hal itu disebut Laporan Polisi. Pengertian laporan polisi tentang manajemen penyidikan adalah laporan tertulis yang dibuat oleh petugas Polri tentang adanya suatu peristiwa yang diduga terdapat pidananya baik yang ditemukan sendiri maupun melalui pemberitahuan yang disampaikan oleh seseorang karena hak atau kewajiban berdasarkan peraturan perundangundangan [5].

Berdasarkan Keputusan Jaksa Agung Republik Indonesia No. 518/A/J.A/11/2001 tentang administrais perkara tindak pidana terdapat kode formulir yang digunakan dalam proses penanganan dan penyelesaian perkara tindak pidana [7]. Kode formulir ini merupakan pemberkasan perkara yang dibuat oleh Kejaksaan dalam menyelesaikan suatu perkara.

Tabel 3 Rangkuman hasil kuesioner

\begin{tabular}{|c|c|c|}
\hline Kode & Isi Surat & Keterangan \\
\hline $\mathrm{P}-1$ & Penerimaan Laporan (Tetap) & Pidsus \\
\hline $\mathrm{P}-2$ & Surat Perintah Penyelidikan & Pidsus \\
\hline $\mathrm{P}-3$ & Rencana Penyelidikan & Pidsus \\
\hline $\mathrm{P}-4$ & Permintaan Keterangan & Pidsus \\
\hline $\mathrm{P}-5$ & Laporan Hasil Penyelidikan & Pidsus \\
\hline P-6 & $\begin{array}{l}\text { Laporan Terjadinya Tindak } \\
\text { Pidana }\end{array}$ & Pidsus \\
\hline P-7 & $\begin{array}{l}\text { Matrik Perkara Tindak } \\
\text { Pidana }\end{array}$ & Pidsus \\
\hline $\mathrm{P}-8$ & Surat Perintah Penyidikan & Pidsus \\
\hline $\mathrm{P}-8 \mathrm{~A}$ & $\begin{array}{l}\text { Rencana Jadwal Kegiatan } \\
\text { Penyidikan }\end{array}$ & Pidsus \\
\hline P-9 & $\begin{array}{l}\text { Surat Panggilan } \\
\text { Saksi/Tersangka }\end{array}$ & Pidum \& Pidsus \\
\hline $\mathrm{P}-10$ & Bantuan Keterangan Ahli & Pidum \& Pidsus \\
\hline $\mathrm{P}-11$ & $\begin{array}{l}\text { Bantuan Pemanggilan } \\
\text { Saksi/Ahli }\end{array}$ & Pidum \& Pidsus \\
\hline $\mathrm{P}-12$ & $\begin{array}{l}\text { Laporan Pengembangan } \\
\text { Penyidikan }\end{array}$ & Pidsus \\
\hline $\mathrm{P}-13$ & $\begin{array}{l}\text { Usul Penghentian } \\
\text { Penyidikan/Penuntutan }\end{array}$ & Pidum \& Pidsus \\
\hline $\mathrm{P}-14$ & $\begin{array}{l}\text { Surat Perintah Pengehentian } \\
\text { Penyidikan }\end{array}$ & Pidum \& Pidsus \\
\hline $\mathrm{P}-15$ & $\begin{array}{l}\text { Surat Perintah Penyerahan } \\
\text { Berkas Perkara }\end{array}$ & Pidsus \\
\hline P-16 & $\begin{array}{l}\text { Surat Perintah Penunjukan } \\
\text { Jaksa Penuntut Umum } \\
\text { untuk Mengikuti } \\
\text { Perkembangan Penyidikan } \\
\text { Perkara Tindak Pidana }\end{array}$ & Pidum \& Pidsus \\
\hline P-16A & Surat Perintah Penunjukan & Pidum \& Pidsus \\
\hline
\end{tabular}




\begin{tabular}{|c|c|c|}
\hline & $\begin{array}{l}\text { Jaksa Penuntutan Umum } \\
\text { untuk Penyelesaian Perkara } \\
\text { Tindak Pidana }\end{array}$ & \\
\hline P-17 & $\begin{array}{l}\text { Permintaan Perkembangan } \\
\text { Hasil Penyelidikan }\end{array}$ & Pidum \& Pidsus \\
\hline P-18 & $\begin{array}{l}\text { Hasil Penyelidikan Belum } \\
\text { Lengkap }\end{array}$ & Pidum \& Pidsus \\
\hline P-19 & $\begin{array}{l}\text { Pengembalian Berkas } \\
\text { Perkara untuk Dilengkapi }\end{array}$ & Pidum \& Pidsus \\
\hline P-20 & $\begin{array}{l}\text { Pemberitahuan bahwa } \\
\text { Waktu Penyidikan telah } \\
\text { Habis }\end{array}$ & Pidum \& Pidsus \\
\hline $\mathrm{P}-21$ & $\begin{array}{l}\text { Pemberitahuan bahwa Hasil } \\
\text { Penyidikan Sudah Lengkap }\end{array}$ & Pidum \& Pidsus \\
\hline $\mathrm{P}-21 \mathrm{~A}$ & $\begin{array}{l}\text { Pemberitahuan Susual Hasil } \\
\text { Penyidikan Sudah Lengkap }\end{array}$ & Pidum \& Pidsus \\
\hline $\mathrm{P}-22$ & $\begin{array}{l}\text { Penyerahan Tersangka dan } \\
\text { Barang Bukti }\end{array}$ & Pidum \& Pidsus \\
\hline P-23 & $\begin{array}{l}\text { Surat Susulan Penyerahan } \\
\text { Tersangka dan Barang Bukti }\end{array}$ & Pidum \& Pidsus \\
\hline $\mathrm{P}-24$ & Berita Acara Pendapat & Pidum \& Pidsus \\
\hline $\mathrm{P}-25$ & $\begin{array}{l}\text { Surat Perintah Melengkapi } \\
\text { Berkas Perkara }\end{array}$ & Pidum \& Pidsus \\
\hline P-26 & $\begin{array}{l}\text { Surat Ketetapan } \\
\text { Penghentian Penuntutan }\end{array}$ & Pidum \& Pidsus \\
\hline $\mathrm{P}-27$ & $\begin{array}{l}\text { Surat Ketetapan Pencabutan } \\
\text { Penghentian Penuntutan }\end{array}$ & Pidum \& Pidsus \\
\hline $\mathrm{P}-28$ & Riwayat Perkara & Pidum \& Pidsus \\
\hline $\mathrm{P}-29$ & Surat Dakwaan & Pidum \& Pidsus \\
\hline $\mathrm{P}-30$ & Catatan Penuntut Umum & Pidum \& Pidsus \\
\hline P-31 & $\begin{array}{l}\text { Surat Pelimpahan Perkara } \\
\text { Acara Pemeriksaan Biasa } \\
\text { (APB) }\end{array}$ & Pidum \& Pidsus \\
\hline $\mathrm{P}-32$ & $\begin{array}{l}\text { Surat Pelimpahan Perkara } \\
\text { Acara Pemeriksaan Singkat } \\
\text { (APS) untuk Mengadili }\end{array}$ & Pidum \& Pidsus \\
\hline P-33 & $\begin{array}{l}\text { Tanda Terima Surat } \\
\text { Pelimpahan Perkara } \\
\text { APB/APS }\end{array}$ & Pidum \& Pidsus \\
\hline $\mathrm{P}-34$ & Tanda Terima Barang Bukti & Pidum \& Pidsus \\
\hline $\mathrm{P}-35$ & $\begin{array}{l}\text { Laporan Pelimpahan } \\
\text { Perkara Pengamanan } \\
\text { Persidangan }\end{array}$ & Pidum \& Pidsus \\
\hline $\mathrm{P}-36$ & $\begin{array}{l}\text { Permintaan Bantuan } \\
\text { Pengawalan/Pengamanan } \\
\text { Persidangan }\end{array}$ & Pidum \& Pidsus \\
\hline $\mathrm{P}-37$ & $\begin{array}{l}\text { Surat Panggilan Saksi } \\
\text { Ahli/Terdakwa/Terpidana }\end{array}$ & Pidum \& Pidsus \\
\hline $\mathrm{P}-38$ & $\begin{array}{l}\text { Bantuan Panggilan } \\
\text { Saksi/Tersangka/Terdakwa }\end{array}$ & Pidum \& Pidsus \\
\hline $\mathrm{P}-48$ & $\begin{array}{l}\text { Surat Perintah Pelaksanaan } \\
\text { Putusan Pengadilan }\end{array}$ & Pidum \& Pidsus \\
\hline Pidsus 5A & $\begin{array}{l}\text { Surat Permintaan } \\
\text { Keterangan }\end{array}$ & Pidsus \\
\hline Pidsus 5B & Surat Bantuan Pemanggilan & Pidsus \\
\hline Pidsus 8 & $\begin{array}{l}\text { Berita Acara Permintaan } \\
\text { Keterangan }\end{array}$ & Pidsus \\
\hline Pidsus 12 & $\begin{array}{l}\text { Pemberitahuan Dimulainya } \\
\text { Penyidikan Perkara } \\
\text { (Internal Kejaksaan Negeri) }\end{array}$ & Pidsus \\
\hline
\end{tabular}

\begin{tabular}{|l|l|l|}
\hline Pidsus 13 & $\begin{array}{l}\text { Pemberitahuan Dimulainya } \\
\text { Penyidikan Perkara }\end{array}$ & Pidsus \\
\hline Pidsus 23 & Surat Perintah Penyitaan & Pidsus \\
\hline BA 4 & $\begin{array}{l}\text { Berita Acara Penelitian } \\
\text { Tersangka }\end{array}$ & Pidum \& Pidsus \\
\hline BA 5 & $\begin{array}{l}\text { Berita Acara Penelitian } \\
\text { Barang Bukti }\end{array}$ & Pidum \& Pidsus \\
\hline BA 7 & Berita Acara Penahanan & Pidum \& Pidsus \\
\hline BA 17 & $\begin{array}{l}\text { Berita Acara Pelaksanaan } \\
\text { Putusan Pengadilan }\end{array}$ & Pidum \& Pidsus \\
\hline BA 20 & $\begin{array}{l}\text { Berita Acara Pengembalian } \\
\text { Jaminan/Barang Bukti }\end{array}$ & Pidum \& Pidsus \\
\hline BA 23 & $\begin{array}{l}\text { Berita Acara Pemusnahan } \\
\text { Barang Bukti }\end{array}$ & Pidum \& Pidsus \\
\hline
\end{tabular}

\section{TERSANGKA}

Menurut J.C.T Simorangkir yang dikutip oleh Andi Sofyan dalam Hukum Acara Pidana Suatu Pengantar, bahwa tersangka adalah seseorang yang telah disangka melakukan suatu tindak pidana dan ini masih dalam taraf pemeriksaan pendahuluan untuk dipertimbangkan apakah tersangka ini mempunyai cukup dasar untuk diperiksa di persidangan. Berdasarkan alur pemberkasan perkara yang terjadi di Kejaksaan Negeri Mempawah, tersangka pada suatu perkara bisa saja menjadi tersangka di suatu perkara yang lain

\section{E. SAKSI}

Yang dimaksud dengan saksi menurut Pasal 1 Angka 26 Kitab Undang Undang Hukum Acara Pidana adalah orang yang dapat memberikan keterangan guna kepentingan penyidikan, penuntutan, dan peradilan tentang suatu perkara pidana yang ia dengar sendiri, ia lihat sendiri dan ia alami sendiri. Saksi dalam suatu perkara dapat lebih dari 1 orang, tergantung dengan perkara yang terjadi

\section{F. BARANG BUKTI}

Hal yang dapat disebut barang bukti adalah:

1. Barang yang dipergunakan untuk melakukan tindak pidana

2. Barang yang dipergunakan untuk membantu melakukan tindak pidana

3. Benda yang menjadi tujuan dari dilakukannya suatu tindak pidana

4. Benda yang dihasilkan dari suatu tindak pidana

5. Benda tersebut dapat memberikan suatu keterangan bagi penyelidikan tindak pidana tersebut, baik barupa gambar ataupun rekaman suara

6. Barang bukti yang merupakan penunjang alat bukti mempunyai kedudukan yang sangat penting dalam suatu perkara pidana. Tetapi kehadiran barang bukti tidak mutlak dalam suatu perkara pidana, karena ada beberapa tindak pidana yang dalam proses pembuktiannya tidak memerlukan 
barang bukti, seperti tindak pidana penghinaan secara lisan.

\section{G. METODE PENGUJIAN}

Pengujian atau dapat disebut juga testing merupakan langkah dalam mendapatkan kepastian dari sistem, dimana yang dimaksudkan untuk mengetahui letak kekurangan atau kesalahan yang terdapat pada system. Pada penelitian ini digunakan dua (2) metode pengujian sistem yaitu metode Blackbox dan metode User Acceptance Test.

\section{H. EMBARCADERO RAD STUDIO XE8}

Embarcadero ${ }^{\circledR}$ RAD Studio XE8 adalah solusi pengembangan perangkat lunak lengkap untuk membangun aplikasi untuk Windows, Mac, iOS dan Android dari singgle codebase. Menggunakan bahasa pemrograman pascal yang sebelumnya dikenal dengan Delphi dan sekarang menjadi Embarcadero Delphi [6].

\section{PENELITIAN DAN PERANCANGAN}

\section{A. ANALISIS SISTEM YANG SEDANG BERJALAN}

Saat ini di Kejaksaan Negeri Mempawah menggunakan metode konvensional. Misalnya pada perkara tindak pidana umum, di Tahap I berkas pertama yang masuk dari penyidik adalah Surat Perintah Dimulainya Penyidikan (SPDP). Di bagian secretariat diregistrasi menggunakan buku besar, setelah diregistrasi SPDP diserahkan ke kasi pidana umum guna penunjukan jaksa, setelah penunjukan jaksa dilakukan, SPDP diberikan ke bagian pra penuntutan dibuatkan surat P-16 dengan menggunakan Microsoft word dan begitu seterusnya sampai dokumen masuk ke Tahap II yaitu tahap penuntutan.

Permasalahan yang ada pada bagian pra penuntutan hingga ke bagian penuntutan yaitu setiap harinya terdapat 10 (sepuluh) hingga 20 (dua puluh) perkara yang masuk. Jika pegawai mencari dokumen perkara harus mencarinya dengan cara manual yaitu mencari satu persatu data di lemari arsip. Pembuatan surat kode formulir perkara juga terhambat, misalnya pada surat penujukan jaksa untuk memantau perkembangan perkara (P-16) dan surat penunjukan jaksa untuk menyelesaiakn perkara (P-16A), data yang dibutuhkan pada masing-masing surat itu antara lain identitas jaksa, identitas perkara, dan identitas tersangka. Namun, karena tidak adanya sistem pengolahan data (database), pegawai harus menginput data perkara, data tersangka dan data jaksa satu persatu dan manual.

\section{B. SISTEM YANG AKAN DIBANGUN}

Berdasarkan hasil observasi langsung ke Kejaksaan Negeri Mempawah maka sistem yang akan dibangun adalah sistem informasi dan manajemen pemberkasan perkara di Kejaksaan Negeri Mempawah adalah sebagai berikut.

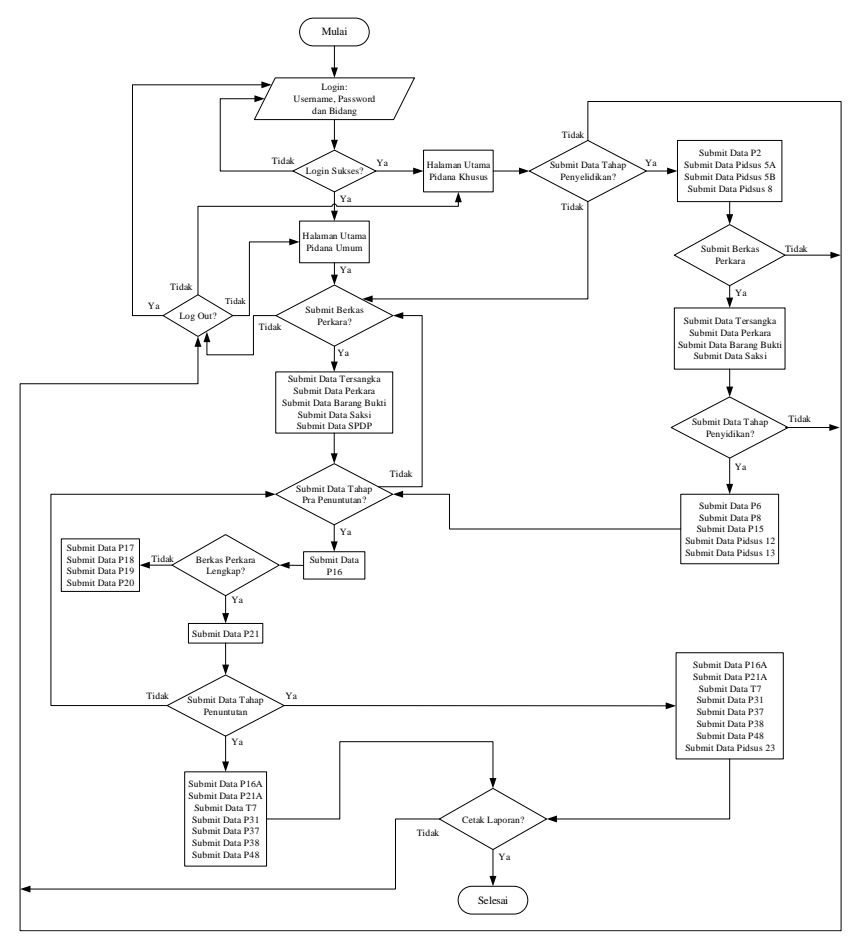

Gambar 1 Alur sistem yang akan dibangun

\section{DESIGN ARSITEKTUR SISTEM}

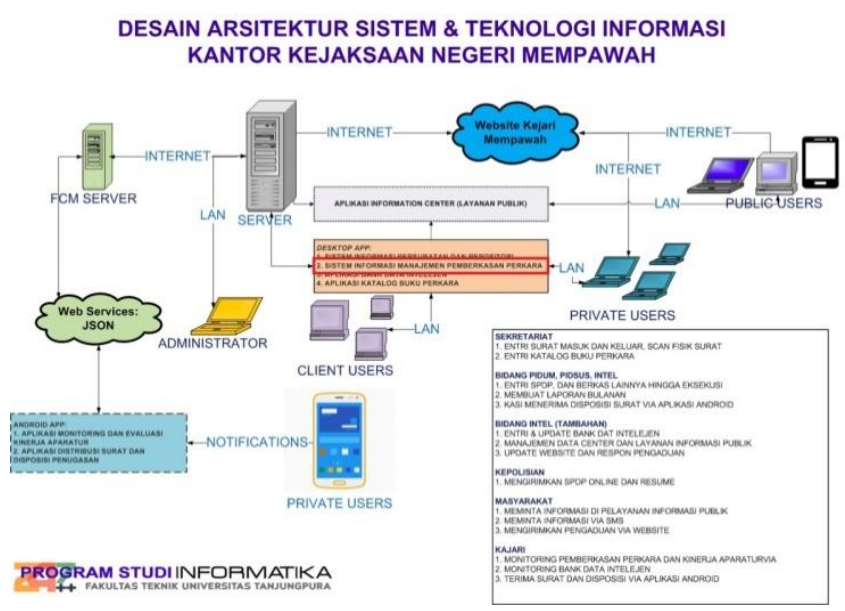

Gambar 2 Arsitektur sistem

Gambar 2 menunjukan desain arsitektur sitem yang dirancang pada Kejaksaan Negeri Mempawah. Terdapat 2 aplikasi yang memiliki hubungan dengan Sistem Informasi dan Manajemen Pemberkasan Perkara. Yang pertama adalah Aplikasi Data Center dan Manajemen Pelayanan Publik, kemudian yang kedua adalah Aplikasi Monitoring 


\section{Dan Evaluasi Kinerja Aparatur di Kejaksaan Negeri Mempawah.}

Sistem Informasi dan Manajemen Pemberkasan Perkara berhubungan dengan aplikasi Data Center dan Manajemen Pelayanan Publik guna menampilkan datadata berkas perkara (yang umum dan tidak bersifat rahasia) untuk dapat di akses publik. Sedangkan Sistem Informasi dan Manajemen Pemberkasan Perkara berhubungan dengan Aplikasi Monitoring dan Evaluasi Kinerja Aparatur adalah guna memberikan notifikasi kepada para jaksa di Kejaksaan Negeri Mempawah jika ada berkas perkara dan surat pemberkasan perkara yang masuk.

\section{DESIGN DIAGRAM OVERVIEW SISTEM}

Diagram overview adalah diagram yang menjelaskan urutan-urutan proses dari diagram konteks. Pada diagram ini dibagi menjadi 7 proses utama yaitu manajemen akun, pembagian jenis pidana pemberkasan perkara, submit data pemberkasan perkara penyelidikan, submit data pemberkasan perkara penyidikan, submit data pemberkasan perkara pra penuntutan, serta submit data pemberkasan perkara penuntutan dan eksekusi.

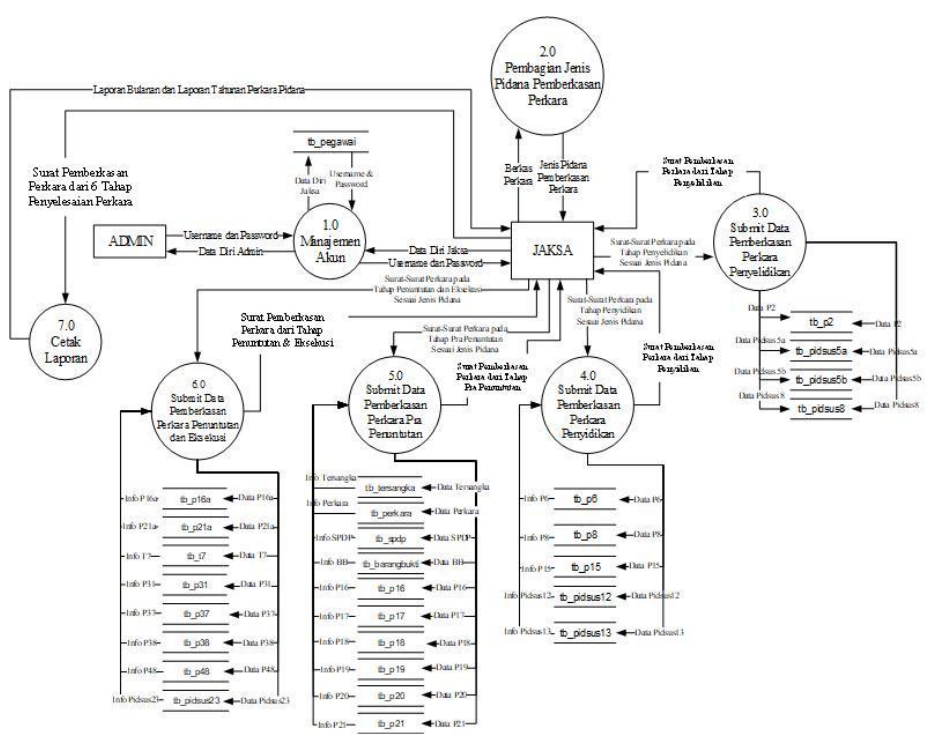

Gambar 3. Diagram Overview Sistem

\section{E. HASIL PERANCANGAN DAN PENELITIAN}

Setelah pengguna berhasil login dan mendapatkan hak akses login pada bidang pidana umum, maka pengguna akan masuk ke halaman pidana umum. Pengguna yang login pada halaman ini tidak dapat menambah data pegawai. Pengguna hanya dapat melihat data pegawai yang sebelumnya telah di input oleh admin.

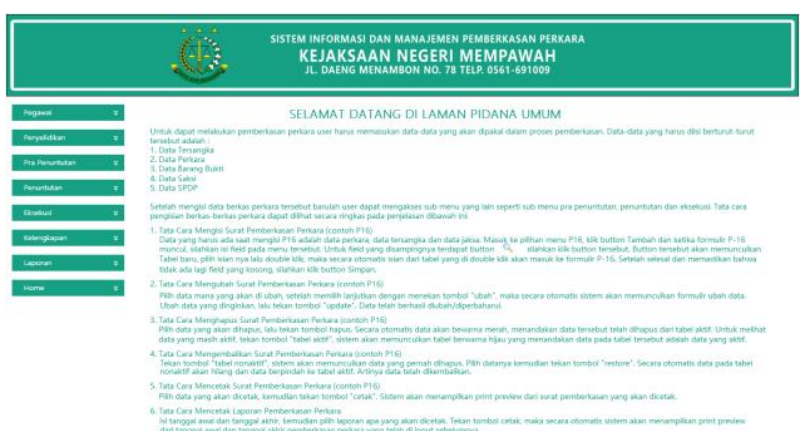

Gambar 4 Antarmuka halaman utama pidana umum

Pemberkasan perkara yang dapat dilakukan oleh pengguna pada halaman ini adalah mengelola sub menu penyelidikan seperti data tersangka, berkas perkara, barang bukti, saksi, dan Surat Perintah Dimulainya Penyidikan (SPDP), kemudian mengolah sub menu pra penuntutan seperti surat P16 hingga P21 sebagai pemberkasan perkara tahap 1 yang akan diserahkan kepada Pengadilan. Setelah pemberkasan perkara dari Pengadilan kembali lagi ke Kejaksaan, pengguna yang login dalam pidana umum ini juga dapat mengelola sub menu penuntutan dan eksekusi yang masing-masing berisi surat seperti T7, P37, P38, P16A, P21A, P31 dan P48. Pengguna pada halaman ini juga dapat mencetak laporan bulanan dan tahunan dengan mengisi tanggal yang telah disiapkan.

Sebagian besar hak akses login yang diberikan pengguna pada halaman pidana khusus dengan halaman pidana umum tidaklah banyak berbeda. Perbedaan hanya terletak pada sub bab penyelidikan dan penyidikan jika pada bagian pidana umum data yang dikelola adalah data telah siap pakai dari kepolisian, maka data pada sub bab penyelidikan dan penyidikan di halaman pidana khusus ini dibuat sendiri oleh pengguna. Oleh sebab itu muncul lah surat-surat yang sebelumnya tidak ada pada halaman pidana umum yaitu P2, Pidsus 5A, Pidsus 5B, Pidsus 8, P6, P8, P15, Pidsus 12 dan Pidsus 13.

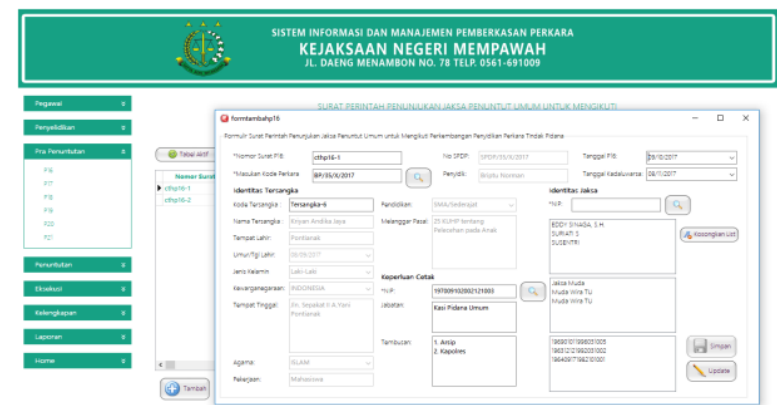

Gambar 5 Antarmuka halaman formulir P16

Gambar 5 adalah antarmuka yang akan muncul ketika pengguna menekan tulisan P16. Semua pemberkasan perkara yang tertera pada aplikasi pada umumnya memiliki 5 tombol utama yaitu tambah, ubah, 
hapus, refresh, restore dan cetak. Setiap tombol memiliki fungsi masing-masing, yaitu:

Tombol tambah akan memunculkan sebuah formulir baru, pada formulir ini semua field kosong dan pengguna diharuskan mengisi semua data yang berhubungan sebelum nantinya data tersebut akan disimpan pada tombol simpan.

Tombol ubah memunculkan formulir yang sama saat menekan tombol tambah, perbedaannya jika pada tombol tambah semua field dikosongkan, maka pada tombol ubah ini semua filed sudah otomatis terisi dengan data yang telah disimpan sebelumnya. Jika pengguna mengubah salah satu isian field lalu menekan tombol update maka data yang bersangkutan telah diubah.

Ketika tombol hapus ditekan dan pengguna mengkonfirmasi penghapusan data, maka data yang telah dipilih sebelumnya akan hilang dari tabel aktif.

Tombol refresh merupakan tombol untuk memuat ulang tabel yang bersangkutan.

Saat salah satu data dihapus, data tersebut sebenarnya tidak benar-benar dihapus, melainkan data tersebut masuk kedalam tabel non aktif. Ketika tombol restore ditekan maka data yang sebelumnya dihapus tersebut dapat dikembalikan.

Ketika tombol cetak ditekan maka data yang telah dipilih akan siap di print.

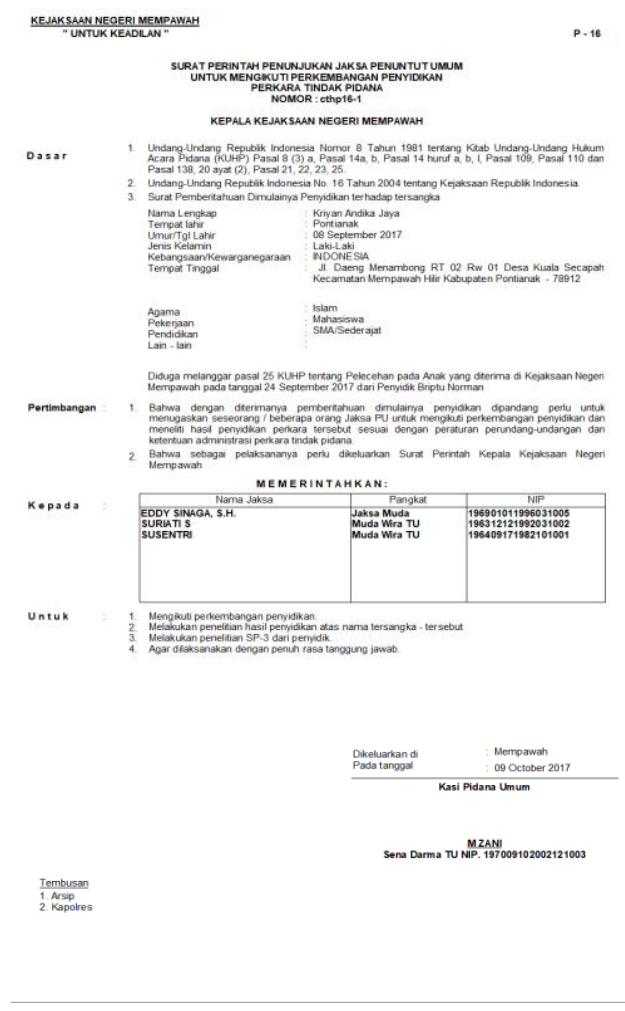

Gambar 6 Hasil cetak surat P16
Salah satu output pada sistem informasi ini adalah dapat mencetak surat pemberkasan perkara. Surat pemberkasan perkara (dalam contoh kali ini adalah surat P16) berisi data-data yang telah pengguna input sebelumnya. Untuk melihat contoh surat P16, pengguna dapat memilih data yang diinginkan lalu menekan tombol cetak, hasilnya akan tampak seperti pada Gambar 6. Hasil semua surat pemberkasan perkara berukuran legal.

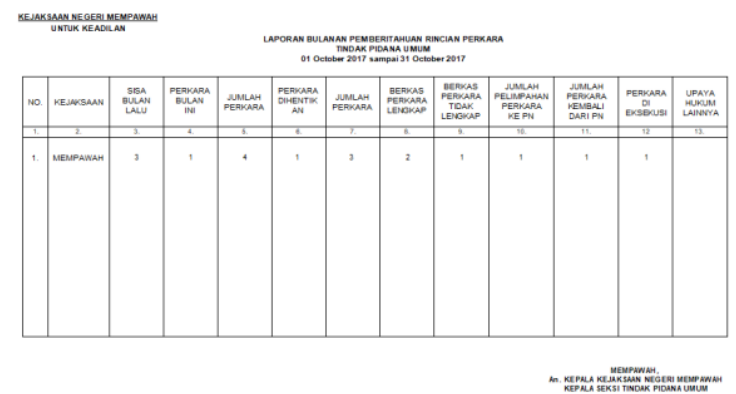

Gambar 7. Hasil cetak laporan bulanan

Laporan merupakan hal paling penting dalam suatu sistem informasi. Fungsi ini dibuat pada sistem untuk memudahkan pengguna dalam hal melaporkan perkaraperkara yang telah masuk sebagai kontrol ke Kepala Kejaksaan. Untuk dapat mencetak laporan pengguna dapat masuk ke halaman cetak laporan perkara pidana, untuk mencetak laporan silahkan pilih tanggal awal dan tanggal akhir yang diinginkan, kemudian tekan tombol cetak sesuai dengan laporan apa yang diinginkan. Sistem secara otomatis akan menampilkan hasil cetak laporan perkara tindak pidana seperti Gambar 7.

\section{PENGUJiAn SISTEM}

Dilakukan dua jenis pengujian pada Sistem Informasi dan Manajemen Pemberkasan Perkara yang telah dibuat pada Kejaksaan Negeri Mempawah. Pengujian pada sistem akan dilakukan dengan menggunakan metode Black Box, sedangkan untuk pengguna sistem dengan menggunakan pengujian User Acceptance Test (UAT).

\section{A. BLACKBOX}

Black-Box testing berfokus pada persyaratan fungsional perangkat lunak yang memungkinkan engineers untuk memperoleh set kondisi input yang sepenuhnya akan melaksanakan persyaratan fungsional untuk sebuah program [8]. Black Box pada perangkat lunak dilakukan untuk menguji kesesuaian antara masukan dengan hasil yang ditampilkan pada aplikasi. 
Tabel 2 Pengujian tambah data

\begin{tabular}{|c|c|c|c|}
\hline Fungsi & $\begin{array}{c}\text { Contoh } \\
\text { fungsi }\end{array}$ & $\begin{array}{c}\text { Hasil } \\
\text { eksekusi }\end{array}$ & Keterangan \\
\hline \multirow{4}{*}{$\begin{array}{c}\text { Tambah } \\
\text { Data }\end{array}$} & $\begin{array}{c}\text { Salah satu } \\
\text { data } \\
\text { dikosongkan }\end{array}$ & $\begin{array}{c}\text { Tidak } \\
\text { berhasil }\end{array}$ & $\begin{array}{c}\text { Data "data } \\
\text { yang kosong" } \\
\text { tidak boleh } \\
\text { kosong }\end{array}$ \\
\cline { 2 - 4 } & $\begin{array}{c}\text { di isi } \\
\text { Semua data } \\
\text { di isi namun } \\
\text { sudah pernah } \\
\text { di isi } \\
\text { sebelumnya }\end{array}$ & Berhasil & $\begin{array}{c}\text { Data sudah } \\
\text { disimpan }\end{array}$ \\
\hline & Tidak & $\begin{array}{c}\text { Datanya sudah } \\
\text { ada }\end{array}$ \\
\hline
\end{tabular}

\section{B. USER ACCEPTANCE TEST (UAT)}

Beberapa pertanyaan yang menggambarkan tingkat kepuasan para pengguna pada Kejaksaan Negeri Mempawah adalah sebagai berikut:

1. Bagaimana reaksi sistem terhadap pengelolaan data pemberkasan perkara pada bidang pidana umum dan pidana khusus seperti menambah, mengubah, menghapus, mengembalikan dan mencetak berkas perkara?

2. Bagaimana reaksi sistem terhadap pengelolan data pemberkasan perkara pada bidang pidana khusus seperti menambah, mengubah, menghapus, mengembalikan dan mencetak berkas perkara?

3. Bagaimana reaksi sistem terhadap pengelolaan data pemberkasan perkara untuk dapat mencetak laporan bulanan dan tahunan perkara pidana umum dan pidana khusus?

4. Bagaimana pemahaman pengguna mengenai sistem informasi dan manajemen pemberkasan perkara?

5. Bagaimana keterkaitan sistem informasi dan manajemen pemberkasan perkara dengan aplikasi monitoring yang terpasang pada masing-masing perangkat jaksa yang bersangkutan?

Tabel 3 Rangkuman hasil kuesioner

\begin{tabular}{|c|c|c|c|}
\hline Responden & Bobot & Bobot Total & Persentase \\
\hline 1 & 23 & 25 & $92 \%$ \\
\hline 2 & 23 & 25 & $92 \%$ \\
\hline 3 & 21 & 25 & $84 \%$ \\
\hline 4 & 22 & 25 & $88 \%$ \\
\hline 5 & 23 & 25 & $92 \%$ \\
\hline Rata-Rata & 23 & 25 & $89,6 \%$ \\
\hline 6 & 22 & 25 & $92 \%$ \\
\hline 7 & 20 & 25 & $80 \%$ \\
\hline 8 &
\end{tabular}

\begin{tabular}{|c|c|c|c|}
\hline 9 & 23 & 25 & $92 \%$ \\
\hline 10 & 23 & 25 & $92 \%$ \\
\hline Rata-Rata & & $88,8 \%$ \\
\hline Rata-Rata Total & $\mathbf{8 9 , 2 \%}$ \\
\hline
\end{tabular}

\section{KESIMPULAN}

Dari hasil pengujian dan analisis terhadap sistem informasi dan manajemen pemberkasan perkara dapat ditarik kesimpulan bahwa sistem yang dibangun dapat berjalan dengan baik serta dapat diterima dan layak dijalankan di lingkungan Kejaksaan Negeri Mempawah.

\section{DAFTAR PUSTAKA}

[1] Republik Indonesia (2004). Undang-Undang Dasar Republik Indonesia Kejaksaan Republik Indonesia Bab 1 Ketentuan Umum Nomor 16 Pasal 2 Ayat 1. Jakarta: Sekretaris Negara.

[2] Terry, G.R (2003). Dasar Dasar Manajemen. Jakarta: Bina Aksara.

[3] Dwiputri, T (2016). Sistem Informasi Manajemen Limbah untuk Simbiosis Usaha Tani dan Ternak. Pontianak, Indonesia: Jurnal Edukasi dan Penelitian Informatika (JEPIN), 2016.

[4] Glosarium (2015). Arti Berkas Perkara. Glosarium.org

[5] Putra, D.I. (2017). Rancang Bangun SIstem Informasi Pengolahan Data Kriminal Berbasis Web pada Bagian Pembinaan Operasional Direktorat Resere Kriminal Umum Polda Kalimantan Barat (Bagbinopsnal Ditreskrim Polda Kalbar). Pontianak, Indonesia: Jurnal Sistem dan Teknologi Informasi (JUSTIN) Vol.5, No. 4, 2017

[6] Kejaksaan Agung Republik Indonesia (2001). Perubahan Keputusan Jaksa Agung Republik Indonesia No. 518/A/J.A/11/2001 tanggal 1 November 2001 tentang Perubahan Keputusan Jaksa Agung Republik Indonesia No. 132/JA/11/1994 tentang Administrasi Perkara Tindak Pidana. Jakarta.

[7] Embarcadero (n.d.). Embarcadero Retrieved September 2017, from http://embarcadero.com

[8] Pressman, R. S (2002). Rekayasa Perangkat Lunak Pendekatan Praktisi. Yogyakarta: Andi. 